Journal of

Literary Education

\title{
Human Rights issues linked to War, Conflict and Peace Reflected in Picturebooks Through Art, Music and Song Lyrics
}

Asuntos sobre los derechos humanos vinculados a la guerra, el conflicto y la paz reflejados en álbumes ilustrados a través del arte, la música y las letras de canciones

Assumptes sobre els drets humans lligats a la guerra, el conflicte i la pau reflectits als àlbums il-lustrats a través de l’art, la música i les lletres de cançons

Janet Evans. Independent Scholar. janetevans@btinternet.com

How to cite this paper:

Evans, Janet (2018). Human Rights issues linked to War, Conflict and Peace Reflected in Picturebooks Through Art, Music and Song Lyrics. Journal of Literary Education, (1), 3957. https://doi.org/10.7203/JLE.1.12442 